\title{
DSM for Motors
} Popular with Utilities and Customers Alike

\section{Demand-side management (DSM) programs for energy-efficient electric motors are effective cost-cutting strategies that utilities can use to help customers reduce their electricity consumption.}

\section{ISTRIBUTION OF THIS DOCUMENT IS UNLA}

Electric motor applications and motor-driven systems account for more than $50 \%$ of the total electricity used in the United States at a cost between $\$ 70$ and $\$ 90$ billion per year. Improving the energy efficiency of motors and motor systems can save
A worker at Eddystone Power Plant in Philadelphia gathers vibration data on a generator. This type of testing helps evaluate equipment performance, increase longevity of the equipment, and ensure the accuracy of maintenance schedules.
$9 \%$ to $23 \%$ of all the electricity used in the United States. Improving motor system efficiency offers opportunities to save cities and counties substantial amounts of money and energy.

An energy-efficient motor that is properly applied uses less electricity to produce the same horsepower as a standard motor. Although energyefficient motors cost about $10 \%$ to $30 \%$ more than standard models, this difference is usually recovered quickly through energy savings. The annual cost of electricity to run a constantly operated motor can easily come to 5 to 10 times the purchase price of the motor. This is analogous to spending $\$ 100,000$ a year for gasoline to operate a $\$ 10,000$ car!

\section{Replacing Motors in Wisconsin}

The benefits of energy-efficient motors go far beyond saving energy. In most applications, these highquality motors are more reliable, longer lasting, quieter, and generate 


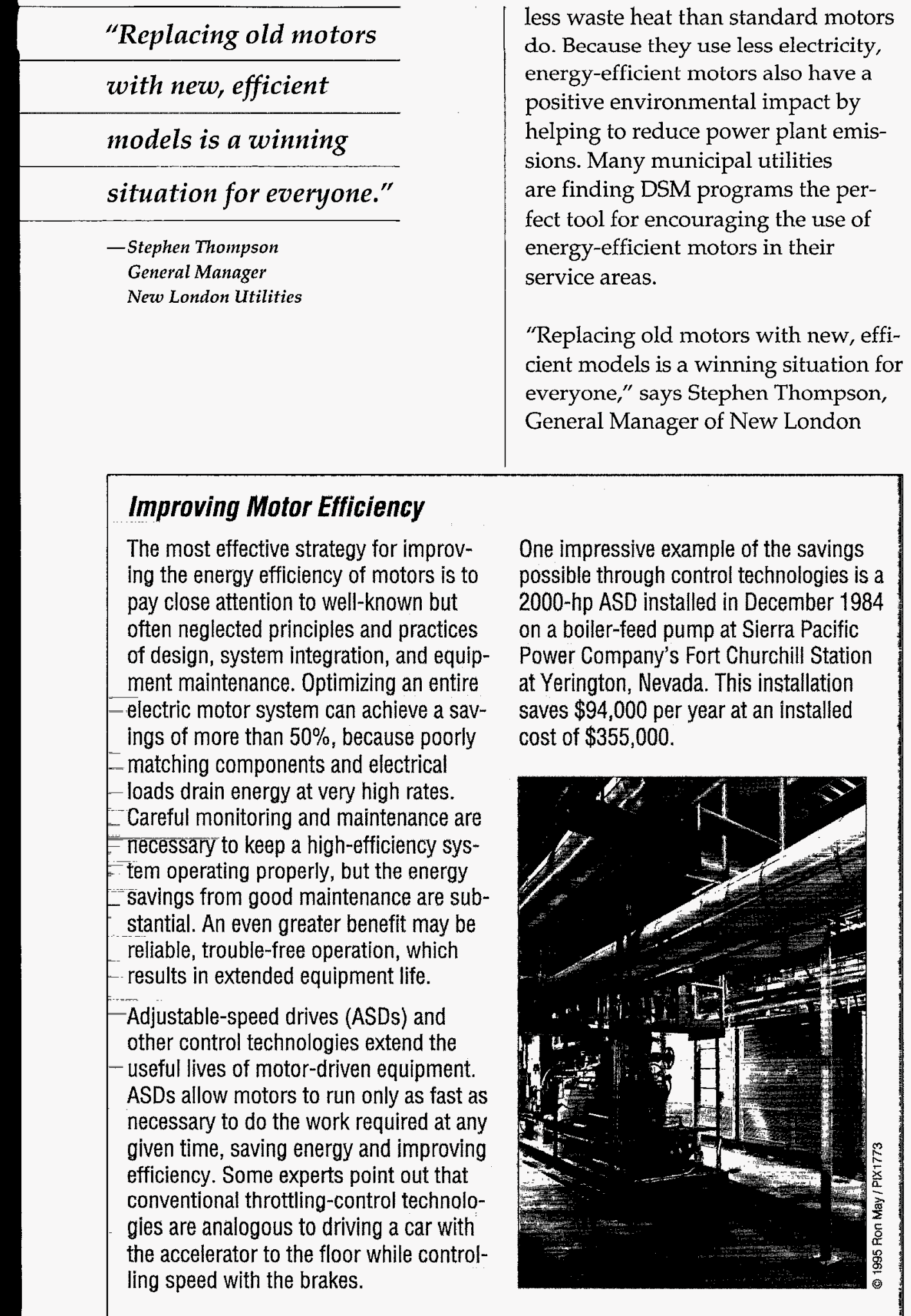

Utilities in New London, Wisconsin. "Large industrial customers run" many of their motors 24 hours a day, every day of the year. By changing out old motors for more efficient units, these customers improve the energy efficiency, productivity, and competitiveness of their operations."

The utility benefits through energy savings, reduced peak demand, and postponement (or even elimination) of capital expenditures for generation, transmission, and distribution system expansions. More than 100 utilities nationwide now have motor DSM programs in place. The most popular strategy for encouraging the use of more efficient motors is to offer rebates to customers who buy energy-efficient motors. New London Utilities adopted a rebate program developed by the Wisconsin Center for Demand-Side Management, an organization funded by most of the utilities in Wisconsin to market DSM programs.

"To generate interest in the program, we approached all 18 of our largest customers," says Thompson. The New London program became an instant success when Hillshire Farms, a large meat processor, decided to replace 239 motors of various sizes with higher efficiency models.

"The project is part of a comprehensive effort by Hillshire Farms to improve energy efficiency and productivity," Thompson explains. "The rebate program made changing out old motors an attractive option for Hillshire, because the rebate improves the economics of replacing old motors. The average simple payback with the rebate is 1.8 years (compared to about 4 years without it), and Hillshire expects to save $\$ 64,300$ every year in energy costs." 


\section{DISCLAIMER}

This report was prepared as an account of work sponsored by an agency of the United States Government. Neither the United States Government nor any agency thereof, nor any of their employees, makes any warranty, express or implied, or assumes any legal liability or responsibility for the accuracy, completeness, or usefulness of any information, apparatus, product, or process disclosed, or represents that its use would not infringe privately owned rights. Reference herein to any specific commercial product, process, or service by trade name, trademark, manufacturer, or otherwise does not necessarily constitute or imply its endorsement, recommendation, or favoring by the United States Government or any agency thereof. The views and opinions of authors expressed herein do not necessarily state or reflect those of the United States Government or any agency thereof. 


\section{DISCLAIMER}

Portions of this document may be illegible in electronic image products. Images are produced from the best available original document. 


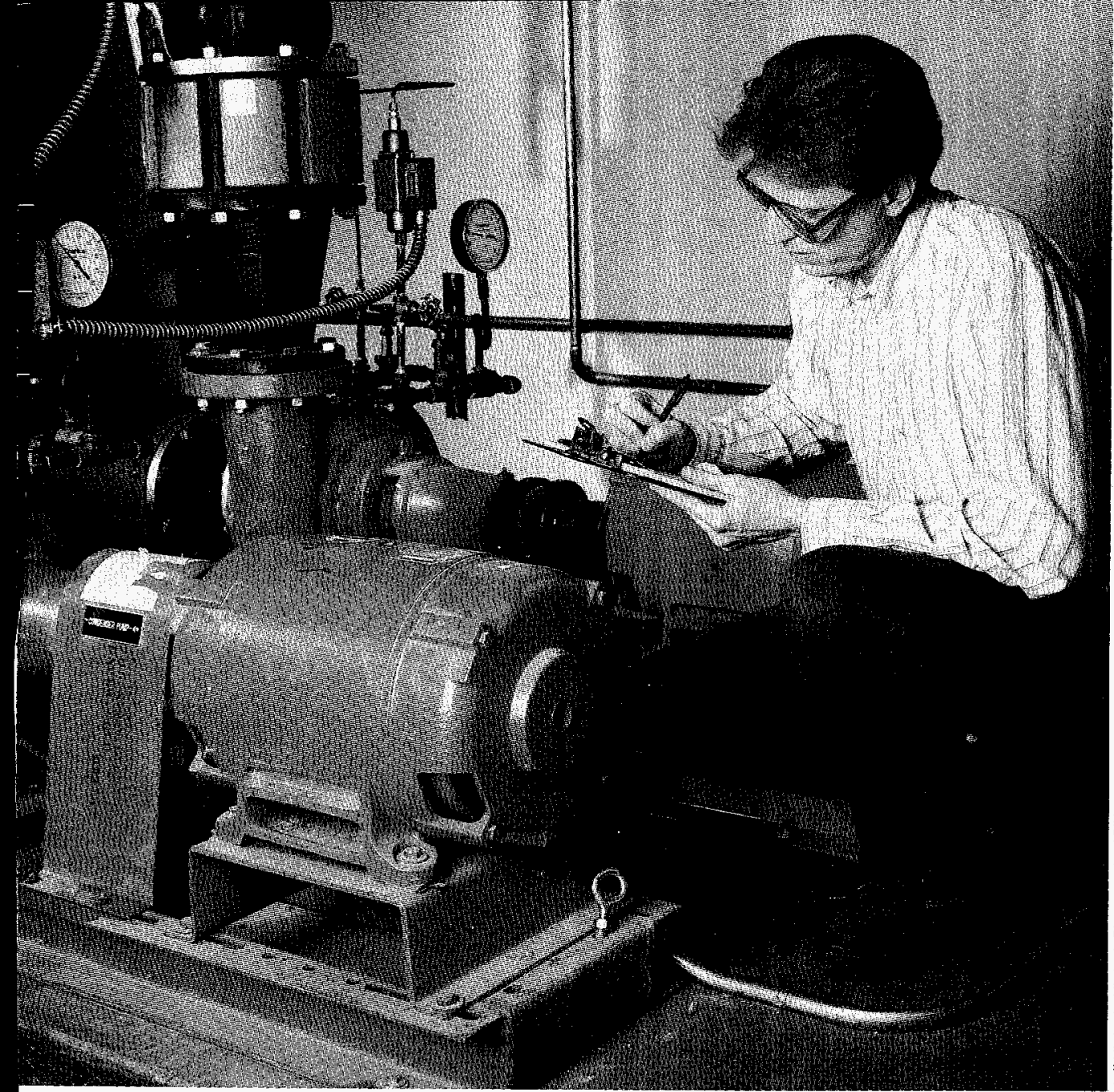

Information available through the Motor Challenge program helps participants save money, increase productivity, and improve environmental quality by using energy-efficient electric motor systems.

\section{A Point-of-Sale Program}

In Washington State, Seattle City Light and Tacoma Public Utilities, together with Puget Power and Light, a private utility, took a different approach and began a joint Regional Premium Motor Rebate Program in February 1994. This is a point-of-sale program designed to improve the efficiency of motors in the utilities' service areas. The participants contracted with the Electric League, a local nonprofit trade association, to administer the program.

The joint program encourages commercial and industrial customers tò purchase and install energy-efficient motors in sizes ranging from
3 horsepower (hp) to $500 \mathrm{hp}$. Purchasers receive instant rebates of as much as $\$ 3250$ at the point of sale (time of purchase), without the need for energy studies or prior approval.

"The customer gets the rebate, which covers the differential between the slightly energy-efficient motor required by local codes and a top-of-the-line model, at the time of the purchase," explains Bob Zdebski of the Electric League. "The dealers then contact me, and I write them checks for the rebates plus an added incentive, and do all the paperwork required by the utility."

Many of the program's features reflect the experiences of successful utility programs in other parts of the country. Rebates are targeted to dealers as well as customers, and the rebates are generous to attract interest. Educating dealers and purchasers about the benefits of upgrading motor efficiencies is also a priority.

Although the Washington program is relatively new, the marketing effort is starting to show results. "We're happy with the participation to date," says Peter Meyer of Tacoma Public Utilities. "By hiring the Electric League, we streamlined the point-ofsale program to make it as easy as possible on dealers and customers of the Puget Sound region to get their rebates. We continued the funding for calendar year 1995 and are hopeful that the volume will increase now that more dealers and customers are aware of the program." 
"We're happy with the

participation to date.

We streamlined the

point-of-sale program

to make it as easy as

possible on dealers and

customers."

- Peter Meyer

Program Manager

Tacoma Public Utilities

\section{Start Saving Now}

Economic, energy, and environmental savings top the list of reasons to improve motor efficiencies. In addition, the federal Energy Policy Act of 1992 sets minimum efficiency standards for motors in an industrial setting. After October of 1997, all new motor purchases must be energy efficient.

Because so much of the life-cycle cost is consumed in operating a motor, improving the efficiency even a few percentage points yields sizable savings. Replacing standard motors today also locks in future energy savings at today's capital cost. Improving motor efficiencies is an excellent opportunity to save money and energy.

\section{Tools for Improving Motor Efficiency}

Tools are available to help overcome the obstacles to improving motor systems' efficiency. MotorMaster is a comprehensive, user-friendly software package designed to help with motor selection and evaluation. This software is especially useful to managers trying to decide whether to repair or replace electric motors in their plant. It was developed by the Washington State Energy Office with funding from the U.S. Department of Energy (DOE) and the Bonneville Power Administration. MotorMaster has specific features designed to support utility-sponsored motor rebate programs. The package includes a database of price and performance information on more than 10,000 motors from all major manufacturers. It can be easily customized for individual utilities, manufacturers/distributors, municipalities, or large corporations. The software is free to all Motor Challenge Partners and is updated annually.

Motor Challenge is a partnership program involving DOE, industry, utilities, motor/drive manufacturers and distributors, and others. The program seeks to

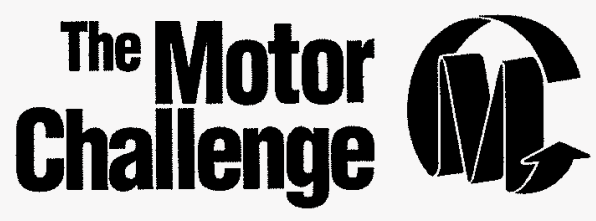

increase the use of energy-efficient electric motor systems in the industrial sector, and encourage partners to build local and regional networks to share motor application success stories across industry lines. The program offers its partners access to reliable and objective product and system information through the Motor Challenge Information Clearinghouse. In addition, the program offers training, technical assistance, and conferences designed to help industrial end users make the most of their motordriven systems.

For more information about MotorMaster or Motor Challenge, contact:
Motor Challenge Information Clearinghouse
P.0. Box 43171
Olympia, WA 98504
(800) 862-2086

Fax (360) 586-8303

\section{For More Information}

Electric Power Research Institute P.O. Box 10412

3412 Hillview Avenue

Palo Alto, CA 94303

(415) 855-2000

EPRI is a utility membership organization that provides information on advances in the generation, delivery, and use of electricity to electric utilities and their customers.

National Electrical Manufacturers Association

2101 L Street, NW

Washington, DC 20037

(202) $457-8400$

NEMA is an electric motor trade organization that sets standards for and distributes publications about electric motors.

Stephen Thompson

New London Utilities

P.O. Box 304

New London, WI 54961

(414) $982-8516$

Fax (414) 982-8544

Mr. Thompson can provide information on New London's demand-side management program for motors.

Rocky Mountain Institute

1739 Snowmass Creek Road

Snowmass, CO 81654-9199

(303) $927-3851$

Fax (303) $927-4178$

orders@rmi.org

RMI offers publications, information, and

training seminars to communities interested In sustainable development.

Peter Meyer

Tacoma Public Utilities

P.O. Box 11007

Tacoma, Washington 98411-0007

(206) 502-8652

Mr. Meyer can provide information on the joint Regional Premium Motor Rebate Program.
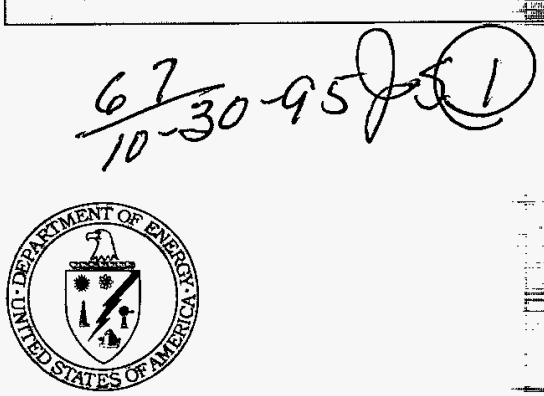

This document was produced for the U.S. Department of Energy (DOE) by the National Renewable Energy Laboratory, a DOE national laboratory. The document. was produced by the Technical Information Program, under the DOE Office of Energy Efficiency and Renewable Energy.

DOE/GO-10095-184

DE95009258

September 1995

Printed with a renewable-source ink on paper containing at least $50 \%$ wastepaper, including $20 \%$ postconsumer raste 